\title{
Levels of Polycyclic Aromatic Hydrocarbons in the Water and Sediment of Buffalo River Estuary, South Africa and Their Health Risk Assessment
}

\author{
A. O. Adeniji ${ }^{1,2}$ (I) O. O. Okoh ${ }^{1,2} \cdot$ A. I. Okoh ${ }^{1,3}$
}

Received: 5 October 2018 / Accepted: 4 March 2019 / Published online: 16 March 2019

(c) The Author(s) 2019

\begin{abstract}
The incidence and spatial distribution of polycyclic aromatic hydrocarbons (PAHs) in the Buffalo River Estuary in the Eastern Cape Province of South Africa were assessed in this study. A total of 60 surface water and 19 sediment samples were collected from 5 sites of the estuary over a period of 6 months (December 2015 to May 2016). Extraction of PAHs from the water and sediment samples was achieved by using liquid-liquid and soxhlet extraction methods respectively, followed by column clean up with silica gel and quantification by gas chromatography-flame ionization detection. Individual PAH levels in the water and sediment samples ranged from not detected (ND) to $24.91 \mu \mathrm{g} / \mathrm{L}$ and ND to $7792 \mu \mathrm{g} / \mathrm{kg}$, respectively. Total concentrations of the PAHs in the water and sediment samples varied as 14.91-206 $\mu \mathrm{g} / \mathrm{L}$ and $1107-22,310 \mu \mathrm{g} / \mathrm{kg}$ in that order. Total levels of the contaminants were above the target values in the two matrices and were higher in summer than autumn. Although the noncarcinogenic risk of PAHs estimated in the water column through dermal absorption was very low compared with the target value, the carcinogenic risk determined was high for both adults and children. Similarly, benzo(a) pyrene and dibenzo(a,h)anthracene were found to be of higher carcinogenic and mutagenic risks in the sediments collected from the study area. Diagnostic ratios suggest that the target hydrocarbons are predominantly from pyrolytic sources. It therefore could be inferred that the water body is conspicuously polluted; hence, efforts should be made to control all the activities contributing to such magnitude of pollution at the sites.
\end{abstract}

Polycyclic aromatic hydrocarbons (PAHs) are priority organic pollutants, which are ubiquitously found in the atmospheric, aquatic, and terrestrial systems and therefore are closely monitored in the environment (Okoro 2008; Sakuma et al. 2011; Adeniji et al. 2018a). They are multiple ring structures having molecular masses in the range of 128 to 278 Dalton (Kumar et al. 2015). A number of them are genotoxic, mutagenic, carcinogenic, and/or teratogenic in nature with long range of transport and well implicated in endocrine system disruption at levels higher than the maximum allowable limit within a very short time (Wilson et al. 2001; Cai et al. 2009; Brazkova and Krastanov 2013).

A. O. Adeniji

adenijigoke@gmail.com

1 SAMRC Microbial Water Quality Monitoring Centre, University of Fort Hare, Alice 5700, South Africa

2 Department of Chemistry, University of Fort Hare, Alice 5700, South Africa

3 Applied and Environmental Microbiology Research Group, Department of Biochemistry and Microbiology, University of Fort Hare, Alice 5700, South Africa
However, few of the nontoxic PAH congeners are found useful as synergists (ATSDR 1995; Adekunle et al. 2017).

Higher molecular members of this class of pollutants are relatively immobile due to their large molecular volumes and are less volatile, relatively insoluble in water, and more lipophilic than the lower molecular members. They also are known to stay longer in the environment (Wild and Jones 1995; Adeniji et al. 2018a). Their hydrophobicity has generated a lot of concerns amongst the general public because of the accompanying risks to humans, environment, and aquatic organisms. They associate freely with dissolved organic matter in the natural water through several means of binding and adsorption, especially those with high molecular weights (Akkanen et al. 2005; Zheng et al. 2007; Smith et al. 2011; Yu et al. 2011; Lin et al. 2018) and are subsequently deposited in the sediment, thus accumulating to a higher level of toxicity in the aquatic environment (Prabhukumar and Pagilla 2010; Brazkova and Krastanov 2013; Olatunji et al. 2014). The bioavailability of PAHs to the aquatic animals and also their penetration of dietary sources has thus become unavoidable (Sakuma et al. 2011; Adeniji et al. 2018b). 
These pollutants are capable of presenting significant health risk to human by oral intake through food, inhalation, and/or even dermal interaction. Exposures through any of the listed routes could bring about health challenges of short- and long-term effects, including some major respiratory and cardiovascular diseases (Perez-Padilla et al. 2010; WHO 2014). Their reactive metabolites, such as epoxides and dihydrodiols, are considered more concerning, given their ability to bind to cellular proteins and DNA and adduct formation (Balbo et al. 2014; Błaszczyk et al. 2017). PAHs are in most cases originated from both natural and anthropogenic origins linked with incomplete combustion of organic materials and release of noncombusted, petrogenic emissions. They enter the environment by way of some natural processes, such as microbial synthesis and volcanic activities, and also through oil exploration and production processes, natural, and intentional burning of biomass and fossil fuels, as well as incomplete combustion of other organic materials including coal (ATSDR 1995; Okoro 2008).

Estuarine and coastal marine environments receive a substantial input of pollutants because of their proximity to land inhabited by humans (Nemcik 2004). Estuaries especially have served as major depositories for the disposal of industrial and domestic effluents, sewage sludge, and dredged material with considerable loads of such contaminants as heavy metals, PAHs, chlorinated hydrocarbons, petroleum hydrocarbons, and radioactive materials coming through pipeline discharges, disposal from vessels, riverine input, vehicular emission, atmospheric deposition, surface runoff, as well as the oil spillage in the aquatic milieus. This makes their presence in the water and sediment matrices a paramount issue with utmost attention for the aquatic environment, fishing, and seafood producing industries (Kennish 1994; Gorleku et al. 2014).

Previous environmental studies at the Buffalo River estuary include assessment of its sediment for heavy metals pollution about two decades ago (RHP 2004) and its water for bacteria load and physicochemical qualities (Chigor et al. 2012, 2013). Those findings revealed gross pollution of both environmental matrices. Recently, fairly high concentrations of total petroleum hydrocarbons, organochlorine pesticides, polychlorinated biphenyls, and some phenolic derivatives also were documented in the zone (Adeniji et al. 2017; Yahaya et al. 2017, 2018, 2019). However, no report is available till date on the status of the polycyclic aromatic hydrocarbons (PAHs) in the area; hence, it became very expedient to investigate, giving its proximity to the river port and some notable industries around. In this paper, the distribution of sixteen (16) priority (PAHs) and their associated health risk in the water and sediment of Buffalo River Estuary, South Africa to humans are reported. Possible sources of the organic contaminants also were predicted using some relevant isomeric ratios.

\section{Materials and Methods}

\section{Description of the Study Area}

Buffalo River Estuary is a large permanently open estuary situated at the East London city in South Africa (DEAT 2010; Whitfield and Baliwe 2013). The 6.5-km-long estuary is found in the downstream of the 126-km-long Buffalo River, which drains into the Indian Ocean (RHP 2004). It is an important estuary among the 139 found in the Eastern Cape Province of South Africa, being the largest River Port in the country, and it plays a major role in the economy of East London (http://soer.deat.gov.za/dm_documents/Theme _Coast_cUAvQ.pdf). It is approximately $2.4-7.4 \mathrm{~m}$ deep and covers 98 ha. It is located at the mouth of the long Buffalo River, which flows through some major towns and industrial areas. The Buffalo River carries runoffs, solid wastes, raw sewage, and industrial effluents received from other large rivers into the estuary (RHP 2004). Examples of such influent rivers are the first and second creeks that contribute significantly to the inflow of domestic and industrial wastes into the aquatic environment (EOHCES 2016). Not less than nine wastewater treatment plants are reportedly discharging effluents into the Buffalo River, which greatly impact its pollution level either directly or indirectly (Chigor et al. 2012, 2013). Some direct users around the estuary include East London Port (where shipping activities are carried out daily), BP South Africa, Chevron (Pty) Ltd, Engen, Total South Africa, Vukani Petroleum, Mercedes Benz South Africa, Sea Spirit Fisheries, and many others (Chimuka et al. 2015; EOHCES 2016). A detailed description of the study area presented in Table 1 and Fig. 1 is available in the previous report by Adeniji et al. (2017).

\section{Reagents, Solvents, and Standards}

Dichloromethane, acetone, and hexane (high performance liquid chromatography grade) and n-Pentane (AR grade) used in the processing and analysis of samples were procured from Merck, South Africa. Reagent grade anhydrous sodium sulphate (Merck, South Africa) used as absorbent, silica gel (100-200 mesh) (Radchem Laboratory Supplies, South Africa) for chromatographic column clean-up and concentrated hydrochloric acid were also purchased. $o$-Terphenyl and 2-fluorobiphenyl (used as surrogate standards) and SV Calibration Mix \#5 (\#31,011) containing $2000 \mu \mathrm{g} /$ $\mathrm{mL}$ each of the 16 priority PAHs also were bought from Restek, USA. Working and surrogate standard solutions were prepared by diluting the stock solutions with HPLC grade $\mathrm{n}$-hexane as required and stored at $4{ }^{\circ} \mathrm{C}$ in the dark for approximately 3 months (Dong et al. 2012). 
Table 1 Description of the Buffalo River Estuary

\begin{tabular}{llllll}
\hline Study site & Stations & Latitude & Longitude & Depth $(\mathrm{m})$ & Description \\
\hline Buffalo River Estuary & E1 & $33.03049^{\circ} \mathrm{S}$ & $27.85821^{\circ} \mathrm{E}$ & 2.40 & Receiving point of the Buffalo river influent \\
& E2 & $33.02788^{\circ} \mathrm{S}$ & $27.86294^{\circ} \mathrm{E}$ & 3.47 & Extension of the Buffalo river influent reception \\
& E3 & $33.02612^{\circ} \mathrm{S}$ & $27.88288^{\circ} \mathrm{E}$ & 4.44 & Industrial Effluent Discharge Point (Second Creek) \\
& E4 & $33.02436^{\circ} \mathrm{S}$ & $27.89072^{\circ} \mathrm{E}$ & 6.16 & Under Steve Biko Bridge (First Creek) \\
& E5 & $33.02332^{\circ} \mathrm{S}$ & $27.89337^{\circ} \mathrm{E}$ & 7.23 & Under Buffalo Bridge \\
\hline
\end{tabular}

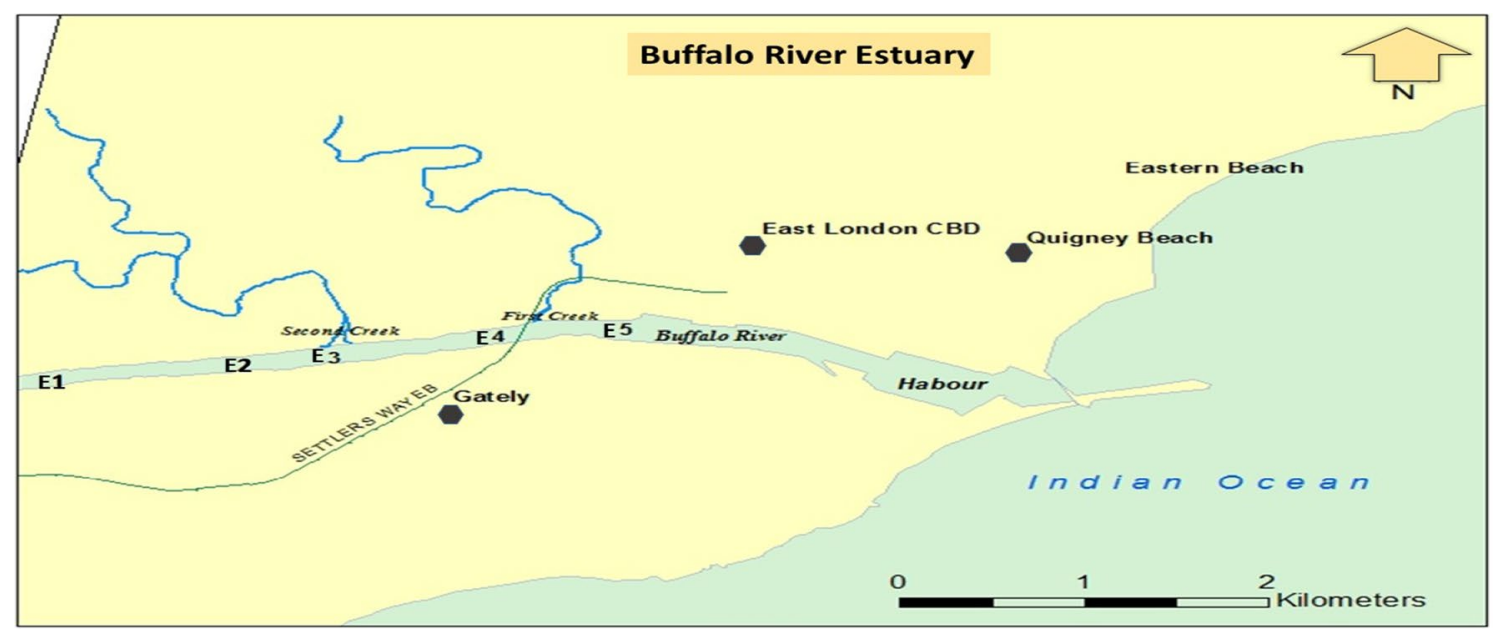

Fig. 1 Map of Buffalo River Estuary

\section{Sample Collection, Extraction, and Clean-Up}

A total of 60 surface water samples were collected early in the morning (between $7 \mathrm{am}$ and $10 \mathrm{am}$ ) in duplicates from 5 sampling locations of the Buffalo River Estuary between December 2015 and May 2016 with precleaned glass bottles. The samples in 1-L amber bottles were adjusted to $\mathrm{pH}<2$ using $6 \mathrm{M}$ of hydrochloric acid, whereas 19 sediment samples (1 kg from each sampling point every month except E5 that was rocky) were collected with Van Veen Grab sampler into wide-mouth bottles. It is worthy of note that water samples were collected all through the 6 months of this research work, but sediment samples were only taken between January and May 2016. Moreover, Site E5 was excluded from sediment sample collection throughout the study period because of its rocky base, whereas E4 was only exempted in May 2016, because no sample was found in spite of several trials. All samples were immediately transported on icechest below $4{ }^{\circ} \mathrm{C}$ to the laboratory for analysis (Gorleku et al. 2014).

One milliliter of surrogate standard mixture $(10 \mu \mathrm{g} / \mathrm{mL})$ was spiked into each $500-\mathrm{mL}$ aliquot of the water sample and extracted three times with liquid-liquid extraction (LLE) technique using n-hexane as solvent. Extracts were combined, dried over anhydrous sodium sulphate, and concentrated using rotary evaporator to a volume of approximately $2 \mathrm{~mL}$ before column clean-up. Sediment samples were air-dried in the dark for approximately 5 days and then were crushed and sieved with $0.5-\mathrm{mm}$ mesh. Approximately $10 \mathrm{~g}$ of the sieved sediment sample was mixed with sufficient amount of anhydrous sodium sulphate, spiked with $1 \mathrm{~mL}$ of the surrogate standard mixture, and extracted in a Soxhlet extractor with $200 \mathrm{~mL}$ of dichloromethane for $24 \mathrm{~h}$. The extract was filtered through anhydrous sodium sulphate into a clean amber glass bottle, concentrated using rotary evaporator and solvent exchanged into n-hexane (WSDE 1997; Kafilzadeh et al. 2011; Adeniji et al. 2018b).

For clean-up, a $10-\mathrm{mm}$ I.D. $\times 30 \mathrm{~cm}$ long chromatographic column was packed with a slurry prepared with $10 \mathrm{~g}$ of activated silica gel in dichloromethane. Approximately $2 \mathrm{~cm}$ of anhydrous sodium sulphate was added on top of the silica gel to absorb moisture. The column was pre-eluted with $20 \mathrm{~mL}$ of n-pentane, and the eluant was discarded. Each sample extract was transferred immediately after pre-elution onto the silica gel column, followed with rinsing of the sample vial and thereafter eluted with $20 \mathrm{~mL}$ of n-pentane. This eluant was collected as aliphatic fraction, and the aromatic fraction was then eluted with $40 \mathrm{~mL}$ of dichloromethane/ pentane $(40: 60)(\mathrm{v} / \mathrm{v})$, concentrated, and solvent exchanged into dichloromethane (WSDE 1997; Kafilzadeh et al. 2011; 
Kumar et al. 2014a). The moisture, organic carbon, and organic matter contents of the sediment samples were gravimetrically determined in accordance with the methods of Motsara and Roy (2008) and Olutona et al. (2016).

\section{Analysis of Polycyclic Aromatic Hydrocarbons}

Agilent 7820A gas chromatograph with HP-5 fused silica capillary column $(30 \mathrm{~m} \times 0.320 \mathrm{~mm}$ i.d. $\times 0.250-\mu \mathrm{m}$ film thickness) and flame ionisation detector was used for the quantification of the analytes of interest. Sample of $1-\mu \mathrm{L}$ volume was injected in splitless mode at a temperature of $280^{\circ} \mathrm{C}$. The oven temperature was programmed to start from $70{ }^{\circ} \mathrm{C}$ (3 min) to $325^{\circ} \mathrm{C}$ at $12{ }^{\circ} \mathrm{C} / \mathrm{min}(6 \mathrm{~min})$. The carrier gas was helium $(99.999 \%)$ at average velocity and flow rate of $29.449 \mathrm{~cm} / \mathrm{sec}$ and $1.6255 \mathrm{~mL} / \mathrm{min}$, respectively. FID temperature was $300{ }^{\circ} \mathrm{C}$, and other detector parameters used are summarised as follows: $\mathrm{H}_{2}$ flow rate: $45.0 \mathrm{~mL} / \mathrm{min}$; air flow rate: $450 \mathrm{~mL} / \mathrm{min}$ and $\mathrm{N}_{2}$ flow rate: $20 \mathrm{~mL} / \mathrm{min}$. Calibration standards were prepared in the working range of $0.05-20 \mu \mathrm{g} /$ $\mathrm{mL}$ by serial dilution with $\mathrm{n}$-hexane (Olatunji et al. 2014). The peak areas calculated using the baseline-baseline mode with Agilent Chemstation software were used to plot calibration curves for all the 16 PAH congeners (Ma et al. 2010; Nekhavhambe et al. 2014). The curves were all linear with correlation coefficients falling within the acceptable range of $r^{2} \geq 0.990$ (Adeniji et al. 2017). Samples were thereafter identified by their retention times, whereas quantification was done by the instrument on the basis of the response factor generated for each congener from the linear curve plotted (Ma et al. 2010; Nekhavhambe et al. 2014).

\section{Probable Carcinogenic and Mutagenic Toxicities of PAHs in the Estuary Sediment}

Potential carcinogenic and mutagenic toxicities of the high molecular weight PAHs detected in the sediment samples collected from the study locations were assessed relative to benzo[a]pyrene (with sufficient toxicological information) using toxic equivalent quotient (TEQ) and mutagenic equivalent quotient (MEQ) as shown in Eqs. (1) and (2), respectively.

$\mathrm{TEQ}=\Sigma C_{n} \cdot \mathrm{TEF}_{n}$

$\mathrm{MEQ}=\Sigma C_{n} \cdot \mathrm{MEF}_{n}$

where $C_{n}=$ concentration of each PAH congener $(n)$ in the mixture. $\mathrm{TEF}_{n}=$ toxic equivalence factor (TEF) for each PAH congener $(n) \cdot \mathrm{MEF}_{n}=$ mutagenic equivalent factor (MEF) for each PAH congener $(n)$. The TEF values used for BaA, Chry, BbF, BkF, BaP, DiahA, Inpy, and BghiP in these calculations were $0.1,0.01,0.1,0.1,1,1,0.1$, and 0.01 , respectively, and their corresponding MEF values were
0.082, 0.017, 0.25, 0.11, 1.0, 0.29, 0.31, and 0.19 (Van den Berg et al. 2006; CCME 2010; Lerda 2011; Benson et al. 2017; Zhao et al. 2017).

\section{Health Risk Assessment to Humans in the Estuary Water}

In this study, health risk to humans was assessed by calculating the potential carcinogenic and noncarcinogenic effects of exposure of a person to the PAHs over a certain period of time (Gerba 2006; US EPA 2001, 2009; Titilawo et al. 2018). The evaluation was done on the basis of exposure by dermal contact only since the waterbody is a recreational environment (EOHCES 2016).

Average daily dosage by dermal contact $\left(\mathrm{ADD}_{\text {derm }}\right)$ expressed in $\mathrm{mg} / \mathrm{kg} / \mathrm{day}$ was calculated for noncarcinogenic risks connected with PAHs in the water column of the study area as shown in Eq. (3).

$\mathrm{ADD}_{\text {derm }}=\frac{C \times \mathrm{SA} \times \mathrm{Kp} \times \mathrm{ET} \times \mathrm{EF} \times \mathrm{ED} \times \mathrm{CF}}{\mathrm{BW} \times \mathrm{AT}}$

where $\mathrm{ADD}_{\text {derm }}$ represents the average daily doses by dermal contact ( $\mathrm{mg} / \mathrm{kg} /$ day); $C$ stands for the concentration of PAHs in the water sample $(\mathrm{mg} / \mathrm{L}) ; \mathrm{EF}$ is the exposure frequency (350 days/year for both ingestion and dermal absorption); ED is the exposure duration (adult: 30 years; child: 6 years); BW represents the average body weight (adult: $70 \mathrm{~kg}$; child: $15 \mathrm{~kg}$ ); AT means the average time, i.e., $\mathrm{ED} \times 365$ days (adult: 10,950 days; child: 2190 days); SA stands for the exposed skin area (adult: 18,000 $\mathrm{cm}^{2}$; child: $6600 \mathrm{~cm}^{2}$ ); Kp $(\mathrm{cm} / \mathrm{h})$ is the dermal permeability coefficient (corresponding values are shown in Tables 4 and 5); ET is the exposure time of shower and bathing (adult: $0.58 \mathrm{~h} /$ day; child: $1 \mathrm{~h} /$ day); and $\mathrm{CF}$ represents the unit conversion factor $(L / 1000 \mathrm{~cm})$. Guidelines values provided by Department of Environmental Affairs, South Africa, and US EPA were used for the estimations (US EPA 1989, 1992; Gerba 2006; DEA 2010; DTSC 2014; Feng et al. 2016a; Wang et al. 2018).

For noncarcinogenic PAHs, hazard quotient (HQ) was calculated by multiplying the ADD with reference dose (RfD) for individual contaminant as presented in Eq. (4). Hazard index (HI) and the sum of HQs also was estimated for all PAH congeners in the samples using Eq. (5) (US EPA 1989; Wei et al. 2015).

$\mathrm{HQ}=\frac{\mathrm{ADD}}{\mathrm{RfD}}$

$\mathrm{HI}=\sum \mathrm{HQs}$

RfD, which represents dermal reference dose for each PAH congener, was not available for other priority compounds except for only six: i.e., naphthalene, fluorene, 
anthracene, phenanthrene, fluoranthene, and benzo(g,h,i) perylene (Table 4).

Moreover, incremental lifetime cancer risk (ILCR) and risk index (RI) were determined for cPAHs found in the water samples using LADD (mg/kg/day), in which Eq. (1) was used to calculate the LADD (by dermal contact) the same way as for ADD, only that AT $=25,550$ was used for the two age categories instead of the previous value. No Kp value was available for BkF; hence, $\mathrm{LADD}_{\text {derm }}$ and $\mathrm{ILCR}_{\mathrm{derm}}$ were not computed for it.

For the calculation of ILCR and RI in the water samples, Eqs. (6) and (7) were used according to US EPA guidelines (USEPA 1989, 2015; Jamhari et al. 2014).

$\mathrm{ILCR}=\mathrm{LADD} \times \mathrm{CSF}$

$\mathrm{RI}=\sum \mathrm{ILCR}$

where CSF represents the cancer slope factor for each PAH congener. CSF for $\mathrm{BaP}$ is $7.3 \mathrm{mg} / \mathrm{kg} /$ day (US EPA 2015). Factors for other PAHs were afterward calculated from the values for BaP by taking a multiple of TEF for each compound and its respective CSF as presented in Table 5 (IARC 2006; Kumar et al. 2015; Wei et al. 2015).

\section{Quality Control and Quality and Assurance}

All of the glass apparatus used were washed and rinsed with tap and distilled water successively. They were subsequently dried in the air circulated oven, cooled, and rinsed with acetone (Dong et al. 2012). Methods blanks were determined alongside the samples in duplicates, and their values were generally below the detection limit (Gorleku et al. 2014; Kumar et al. 2014a). Limits of detection and quantification for all the selected contaminants ranged from 0.01 to $0.03 \mu \mathrm{g} / \mathrm{L}$ and 0.04 to $0.15 \mu \mathrm{g} / \mathrm{L}$, respectively, whereas their relative standard deviations varied between $0.59 \%$ and $2.51 \%$. Concentrations below detection limits were recorded as zero in calculation but reported as not detected (Jiao et al. 2012; Gorleku et al. 2014; Olatunji et al. 2014; Kumar et al. 2015). The overall mean recovery of PAHs in both water and sediment samples were found to be $79.53 \%$ and $72.20 \%$, correspondingly in agreement with literatures (US EPA 2003; Kelly et al. 2000; Gorleku et al. 2014). Likewise, the recoveries of surrogate standards were within the acceptable range and so were used to correct the concentrations of the analytes of interest in the samples (Mirza et al. 2012; ESS Laboratory 2008; KDHE 2015).

\section{Statistical Analyses}

Descriptive statistics and analysis of variance were carried out using stataIC 12 (64-bit) to assess means and standard deviations of data, as well as the disparity between and within them in groups. The $p$ value $<0.05$ was considered significant cutoff.

\section{Results and Discussion}

\section{Levels of PAHs in the Water Samples from Buffalo River Estuary}

The levels of PAHs in the water column of Buffalo River Estuary are given in Table 2. All 16 priority PAHs of the United States Environmental Protection Agency (US EPA) were detected in the water samples collected from the estuary at varied concentrations, confirming the ubiquitous nature of the pollutants (Jiao et al. 2012; Wang et al. 2018). Individual levels of PAHs in the water phase ranged from nondetected (ND) to $24.91 \mu \mathrm{g} / \mathrm{L}$ (indeno(1,2,3-cd)pyrene). The most and least frequently detected of the pollutants were benzo(a)anthracene (90\%) and acenaphthylene (7\%), respectively. As shown in Table 2, naphthalene, chrysene, and benzo(a)pyrene (a group 1 carcinogen) exceeded their maximum allowable concentrations (MAC) in fresh and marine waters (British Columbia 1993). Permissible limit of $0.2 \mu \mathrm{g} / \mathrm{L}$ set by Agency for Toxic Substances and Disease Registry (ATSDR 2009) for benzo(a)pyrene also was exceeded. The total concentrations of the 16 PAHs ( $\sum$ PAHs) varied in water from 14.91 to $206 \mu \mathrm{g} / \mathrm{L}$ with a mean value of $76.06 \pm 11.01 \mu \mathrm{g} / \mathrm{L}$ (Table 2). Guidelines from other countries were used in this study, because no limit is at the moment set in South Africa for PAHs in different compartments of environment (Chimuka et al. 2015).

Highest total concentration of PAHs $(78.55 \mu \mathrm{g} / \mathrm{L})$ in the estuary waters was observed at E1 (the shallow entry point of the Buffalo River water into the estuary), followed by E4 $(73.03 \mu \mathrm{g} / \mathrm{L})$ and E3, second creek $(65.06 \mu \mathrm{g} / \mathrm{L})$. The levels at E1 may be attributed to pollution load along the course of the river from major towns, such as Zwelisha, King Williams Town, and Mdantsane, whereas the pollution at E4 may be related to probable leakage of petroleum products from twostroke engines of the fishing boats, which are usually parked at the Fish Market in the area, stormwater from East London harbour, vehicular emissions from Steve Biko Bridge, and nonpoint source pollution that enters the waterbody as runoff and sewerage through the first creek (RHP 2004; EOHCES 2016). Similarly, PAHs' contamination of water at E3 cannot be unconnected with the discharge of industrial wastewater and accumulation of leachates at the creek possibly from an old solid waste landfill site, wastewater treatment facilities, and Wilsonia industrial and residential areas (Adeniji et al. 2017). Concentrations of the organic contaminants in all the sampling points were higher than the target value of $30 \mu \mathrm{g} / \mathrm{L}$ for PAHs in the marine waters (Fig. 2) (DoE 2003). 
Table 2 Concentrations of the 16 priority PAHs in the water and sediment samples from Buffalo River Estuary

\begin{tabular}{|c|c|c|c|c|c|c|c|c|c|}
\hline \multirow[t]{2}{*}{ PAHs } & \multicolumn{4}{|l|}{ Surface water } & \multicolumn{5}{|l|}{ Sediment } \\
\hline & Range $(\mu \mathrm{g} / \mathrm{L})$ & Mean $(\mu \mathrm{g} / \mathrm{L})$ & MAC $(\mu \mathrm{g} / \mathrm{L})$ & $\mathrm{FD}(\%)$ & Range $(\mu \mathrm{g} / \mathrm{kg})$ & Mean $(\mu \mathrm{g} / \mathrm{kg})$ & $\mathrm{ERL}(\mu \mathrm{g} / \mathrm{kg})$ & $\mathrm{ERM}(\mu \mathrm{g} / \mathrm{kg})$ & $\mathrm{FD}(\%)$ \\
\hline Naphthalene & $\mathrm{ND}-12.69$ & $6.94 \pm 0.6$ & 1 & 17 & $\mathrm{ND}-652$ & $361 \pm 40.2$ & 160 & 2100 & 42 \\
\hline Acenaphthylene & ND-14.29 & $7.39 \pm 1.78$ & NR & 7 & ND -816 & $119 \pm 43.28$ & 44 & 640 & 84 \\
\hline Acenaphthene & ND_19.03 & $3.05 \pm 1.29$ & 6 & 23 & $\mathrm{ND}-731$ & $177 \pm 61.11$ & 16 & 500 & 74 \\
\hline Fluorene & $\mathrm{ND}-12.11$ & $3.59 \pm 0.50$ & 12 & 63 & ND -1380 & $435 \pm 96.4$ & 19 & 540 & 95 \\
\hline Anthracene & $\mathrm{ND}-7.81$ & $1.97 \pm 0.32$ & NR & 47 & ND -749 & $230 \pm 59.41$ & 853 & 1100 & 95 \\
\hline Phenanthrene & $\mathrm{ND}-14.22$ & $3.59 \pm 0.76$ & NR & 47 & $N D-476$ & $173 \pm 33.24$ & 240 & 1500 & 95 \\
\hline Fluoranthene & $\mathrm{ND}-0.54$ & $0.24 \pm 0.04$ & NR & 13 & $N D-456$ & $109 \pm 28.66$ & 600 & 5100 & 74 \\
\hline Pyrene & $\mathrm{ND}-8.72$ & $1.32 \pm 0.35$ & NR & 60 & $N D-923$ & $125 \pm 50.24$ & 665 & 2600 & 95 \\
\hline $\begin{array}{l}\text { Benzo(a)anthra- } \\
\text { cene }\end{array}$ & ND-10.34 & $3.24 \pm 0.45$ & NR & 90 & $56.94-1490$ & $223 \pm 73.36$ & 261 & 1600 & 100 \\
\hline Chrysene & ND-19.01 & $4.39 \pm 0.82$ & 0.1 & 87 & ND-1015 & $398 \pm 67.47$ & 384 & 2800 & 95 \\
\hline $\begin{array}{l}\text { Benzo(b)fluoran- } \\
\text { thene }\end{array}$ & $\mathrm{ND}-7.41$ & $3.52 \pm 0.37$ & NR & 70 & $33.49-1107$ & $325 \pm 81.7$ & NA & NA & 100 \\
\hline $\begin{array}{l}\text { Benzo(k)fluoran- } \\
\text { thene }\end{array}$ & $\mathrm{ND}-9.26$ & $3.12 \pm 0.41$ & NR & 60 & $\mathrm{ND}-772$ & $205 \pm 40.65$ & NA & NA & 79 \\
\hline Benzo(a)pyrene & $\mathrm{ND}-6.25$ & $3.29 \pm 0.31$ & 0.01 & 73 & $\mathrm{ND}-351$ & $185 \pm 21.48$ & 430 & 1600 & 90 \\
\hline $\begin{array}{c}\text { Dibenzo(a,h) } \\
\text { anthracene }\end{array}$ & ND-19.34 & $11.41 \pm 0.95$ & NR & 43 & ND_-2799 & $827 \pm 167$ & 63.4 & 260 & 79 \\
\hline $\begin{array}{l}\text { Indeno(1,2,3-cd) } \\
\text { pyrene }\end{array}$ & $\mathrm{ND}-24.91$ & $7.2 \pm 1.03$ & NR & 67 & ND_-7792 & $712 \pm 420$ & NA & NA & 79 \\
\hline $\begin{array}{l}\operatorname{Benzo}(\mathrm{g}, \mathrm{h}, \mathrm{i}) \\
\text { perylene }\end{array}$ & ND-20.26 & $11.79 \pm 1.03$ & NR & 47 & ND -801 & $456 \pm 33.76$ & NA & NA & 79 \\
\hline$\sum$ PAHs & $14.91-206$ & $76.06 \pm 11.01$ & & - & $1107-22,310$ & $5060 \pm 1319$ & 4000 & 44,792 & - \\
\hline$\sum \mathrm{LMW}$ & ND-53.24 & $26.53 \pm 5.25$ & & - & $37.45-2538$ & $1496 \pm 334$ & - & - & - \\
\hline$\sum$ HMW & ND—90.56 & $49.53 \pm 5.76$ & & - & $383-9747$ & $3564 \pm 985$ & - & - & - \\
\hline$\sum \mathrm{cPAHs}$ & $6.66-96.53$ & $36.17 \pm 4.34$ & & - & $674-15,326$ & $2875 \pm 872$ & - & - & - \\
\hline
\end{tabular}

$\sum P A H s$ sum of polycyclic aromatic hydrocarbons, $\sum c P A H s$ sum of carcinogenic polycyclic aromatic hydrocarbons, $\sum L M W$ sum of low molecular weight PAHs, $\Sigma H M W$ sum of high molecular weight PAHs, $F D$ frequency of detection, $M A C$ maximum allowable concentrations, ERL effects range low, ERM effects range median, $N R$ not recommended (British Columbia 1993; Jiao et al. 2012)

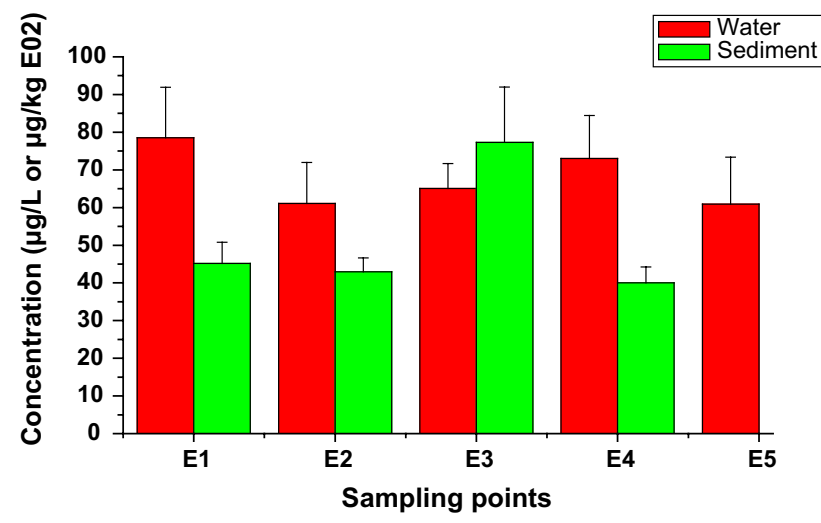

Fig. 2 Spatial variability of PAHs in the Buffalo River Estuary

The amount of the congeners recorded in summer $(64.21 \mu \mathrm{g} / \mathrm{L})$ was higher than in autumn $(57.33 \mu \mathrm{g} / \mathrm{L})$ as shown in Fig. 3. This may be linked with increasing runoff in

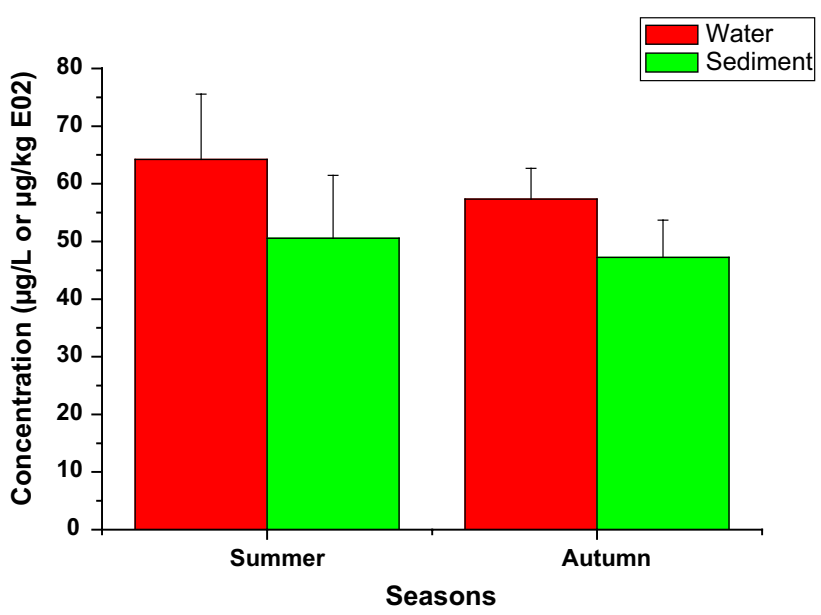

Fig. 3 Seasonal concentrations of PAHs in Buffalo River Estuary 
the season through which contaminants were possibly swept into the aquatic environment (Kumar et al. 2014a; Adeniji et al. 2017). The total mean concentrations of PAHs in the water compartment of Buffalo River Estuary were above the levels found in the middle and lower reaches of the Yellow River, China (Li et al. 2006), comparable to those reported for Ekpan Creek, Warri, Nigeria (Okoro 2008), and Tema Harbour, Ghana (Gorleku et al. 2014) and were below those found in some major rivers in Limpopo Province, South Africa (Nekhavhambe et al. 2014; Edokpayi et al. 2016).

\section{Levels of PAHs in the Sediment Samples from Buffalo River Estuary}

The concentrations of the 16 PAHs of concern in the surface sediment of Buffalo River Estuary, expressed on dry weight (dw) basis are given in Table 2. Benzo(a)anthracene (100\%) and benzo(b)fluoranthene (100\%) were the most detected of all, whereas naphthalene (42\%) was the least. Individual PAHs in the sediment samples were found with concentrations in the range of ND to $7792 \mu \mathrm{g} / \mathrm{kg}$ (indeno(1,2,3-cd) pyrene). Total concentrations, calculated as sum of the 16 PAHs in the estuary sediment varied from $1107 \mu \mathrm{g} / \mathrm{kg}$ to $22,310 \mu \mathrm{g} / \mathrm{kg}$, having an average of $5060 \pm 1319 \mu \mathrm{g} / \mathrm{kg}$ which was much higher than the effect range low (ERL) of $4000 \mu \mathrm{g} / \mathrm{kg}$. Naphthalene, acenaphthylene, acenaphthene, fluorene, chrysene, and dibenzo(a,h)anthracene also were determined at levels higher than their respective ERLs as shown in Table 2, which suggest that the aquatic organisms, especially the benthic invertebrates in the water milieu might suffer possible adverse biological effects (MacDonald et al. 2000). It worthy to note that the level of benzo(a)pyrene in the estuary sediment was below its ERL value of $430 \mu \mathrm{g} / \mathrm{kg}$ (Dong et al. 2012; Jiao et al. 2012).

Sediment samples were collected only in the first four sampling points of the study site, because the last point under Buffalo Bridge (E5) was rocky; hence, no sample was collected from there throughout the lifetime of this work. The distribution of PAHs in the estuarine sediment revealed that second creek (E3) was the most polluted $(7728 \mu \mathrm{g} / \mathrm{kg} \mathrm{dw})$, followed by E1, the shallow entry point of Buffalo River $(4515 \mu \mathrm{g} / \mathrm{kg} \mathrm{dw})$ as shown in Fig. 2. The fairly low level of $\sum$ PAH recorded at E4 may be ascribed to the possible tidal flushing of contaminants adsorbed on sediment particle close to the mouth of the estuary where it discharges into the Indian Ocean (Zhao et al. 2017). Average levels at the four sampling points were all above the ERL and below effect range median (ERM; 44,792 $\mu \mathrm{g} /$ $\mathrm{kg} \mathrm{dw}$ ). They were found within the intermediate range of ERL-ERM, suggesting occasional adverse biological effects to the aquatic animals. Concentrations above ERM value is an indication of adverse effects on the ecosystem and likely danger to human health as well (Jiao et al.
2012; Tornero and d'Alcalà 2014; Adeniji et al. 2018a, b). The concentrations recorded in this study therefore imply that the estuary is fairly polluted with PAHs. Possible sources of PAHs in the estuary, especially at first and second creeks, could be related to effluent from automobile and petrochemical industries contaminates in the area, leachate from the nearby landfill site, West Bank Hood Point domestic and industrial wastewater channels, vehicle emissions on the highways, and urbanised subcatchments' drains from the East London City Centre (RHP 2004; Okoro 2008; Kafilzadeh et al. 2011; Sule et al. 2011; EOHCES 2016).

The percentage organic carbon (OC) in the sediment samples ranged from $5.17 \%$ (E4, first creek) to $6.78 \%$ (E2, Buffalo River influent) with a mean value of $6.14 \%$. The relationship between the \%OC and total concentration of PAHs in the sediment samples was assessed and the Pearson correlation obtained was though positive but weak $(r=0.469, p<0.1)$, implying that organic carbon content has little contribution to the sorption of PAHs to the estuary sediment (Jiao et al. 2012). Therefore, OC and PAHs found in the sediments might be from different origins and might as well be affected by dissimilar biogeochemical processes (Kang et al. 2009). Assimilation of organic and inorganic wastes in the sediment possibly from occasional leakage of oil from the harbour and other port activities in the estuarine zone, as well as continuous discharge of industrial effluents into the waterbody could to an extent be contributory the level of organic carbon recorded (EOHCES 2016). High levels of OC in the estuary can greatly influence the sorption, desorption, and/ or biodegradation of PAHs, and as well determine their level of accumulation in the sediment subsequently, causing great harm to the aquatic organisms in the ecosystem (Prabhukumar and Pagilla 2010; Jiao et al. 2012; Brazkova and Krastanov 2013). Concentrations of PAHs determined in summer $(5056 \mu \mathrm{g} / \mathrm{kg})$ were higher than in autumn $(4724 \mu \mathrm{g} / \mathrm{kg})$, which also was the case with the water samples (Fig. 3). This might result from strong rainfall in the season, possibly carrying large amount of the contaminants into the waterbody in the form of runoff from the highways and drainages of the urban city of East London and industrial areas in the neighbourhood ( $\mathrm{Li}$ et al. 2017). Comparatively, the levels of PAHs obtained in the Buffalo River Estuary sediments were similar to those from Casco Bay, Maine, Texas (Kennicutt II et al. 1994), Sydney Harbour (Montoya 2015), Delhi, India (Kumar et al. 2014a), Xinxiang, China (Feng et al. 2016b), major rivers in Limpopo Province, South Africa (Edokpayi et al. 2016), and marine environment, Korea (Yim et al. 2005) but were higher than the concentrations reported for middle and lower reaches of the Yellow River, China (Li et al. 2006). 


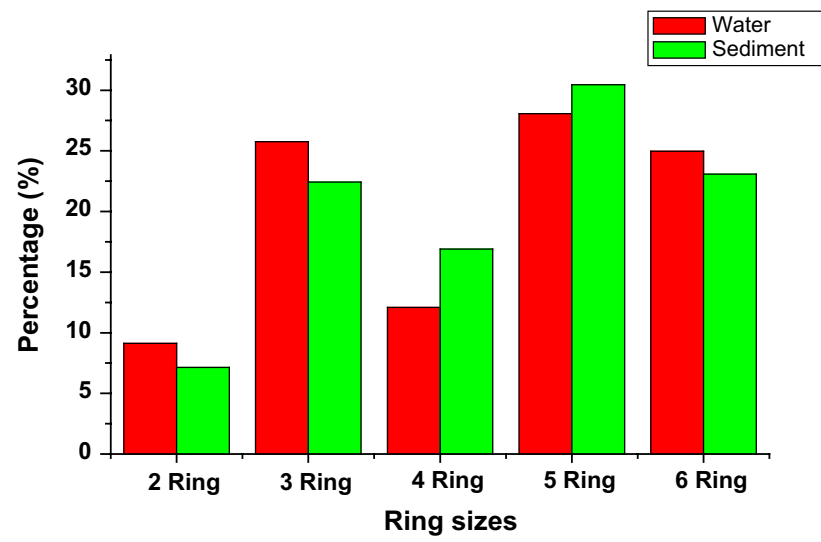

Fig. 4 Relative abundance of PAHs in the Buffalo River Estuary

Table 3 Molecular diagnostic ratios and possible sources of PAHs in the water and sediment samples from Buffalo River Estuary

\begin{tabular}{lllll}
\hline PAHs & Petrogenic & Pyrolytic & Surface water & Sediment \\
\hline Anth/178 & $<0.1$ & $\geq 0.1$ & $0.01 \pm 0.001$ & $1.22 \pm 0.33$ \\
Anth/ & $<0.1$ & $>0.1$ & $0.5 \pm 0.07$ & $0.44 \pm 0.06$ \\
$\quad$ Anth + Phen & & & & \\
$\mathrm{BaA} / 228$ & $<0.2$ & $0.2-0.35$ & $0.01 \pm 0.002$ & $0.98 \pm 0.32$ \\
$\mathrm{BaA} /$ & $<0.2$ & $0.2-0.35$ & $0.52 \pm 0.05$ & $0.41 \pm 0.06$ \\
$\mathrm{BaA}+\mathrm{Chry}$ & & & & \\
$\mathrm{Chry} / \mathrm{BaA}$ & $<0.4$ & $>0.9$ & $2.19 \pm 0.62$ & $3.09 \pm 0.69$ \\
Flt/Pyr & $<1.0$ & $>1.0$ & $0.05 \pm 0.03$ & $1.67 \pm 0.56$ \\
Flt/Flt+Pyr & $<0.4$ & $>0.4$ & $0.04 \pm 0.02$ & $0.4 \pm 0.09$ \\
InPy/ & $<0.2$ & $>0.2$ & - & $0.47 \pm 0.06$ \\
InPy + BghiP & & & & \\
LMW/HMW & $>1.0$ & $<1.0$ & $0.54 \pm 0.91$ & $0.42 \pm 0.34$ \\
Phen/Anth & $>15$ & $<10$ & $0.61 \pm 0.12$ & $2.38 \pm 0.91$ \\
\hline
\end{tabular}

Phen phenanthrene, Anth anthracene, Chry chrysene, BaA benzo[a] anthracene, Flt fluoranthene, $P y r$ pyrene, InPy indeno(123,cd)pyrene, $B g h i P$ benzo[g,h,i]perylene, $L M W$ low molecular weight, $H M W$ high molecular weight (Moyo et al. 2013; Adeniji et al. 2018a, b)

\section{Ring sizes, Diagnostic Ratios, and Possible Sources of PAHs in the Estuary}

Ring size distribution followed a decreasing order $5>3>6>4>2$ in water samples and $5>6>3>4>2$ in the sediment samples (Fig. 4). This shows that 5 rings PAHs were the most abundant in both environmental matrices, although the water samples were distinguished with higher percentage of 3 rings compounds, whereas 6 rings PAHs were more abundant in the sediment samples (Nekhavhambe et al. 2014). Distribution of high molecular weight PAHs (HPAHs) and low molecular weight PAHs (LPAHs) were calculated to identify the possible sources of PAHs pollution in the estuary. The ratio $\Sigma \mathrm{LMW} / \Sigma \mathrm{HMW}$ was lower than 1 in all the sampling points (Table 3 ), meaning that the concentration of the HPAHs (which are more toxic) was generally higher in the environment than the LPAHs, suggesting a dominant pyrolytic input rather the petrogenic sources in both water and sediment matrices (Hasanati et al. 2011; Kafilzadeh et al. 2011; Onojake et al. 2014). It is understandable because the LPAHs are characteristically volatile and more biodegradable, unlike the HPAHs which are more persistent in the environment (Doan 2005).

Other diagnostic ratios of specific PAH congeners and their isomers have been used as geochemical tracers and also to distinguish natural and anthropogenic sources of PAHs in urban and rural areas (Mirza et al. 2012). Ten of such ratios were in all selected for use in this study (Table 3). Approximately eight of them pointed to pyrolytic origins in the sediment, whereas only four agreed with that prediction in the water phase. Another four diagnostic ratios (Anth/178, $\mathrm{BaA} / 228$, Flt/Pyr, and Flt/Flt + Pyr) in the water column, however, suggested predominant petrogenic sources of PAHs in the area (Douglas et al. 2007; Hasanati et al. 2011; Kafilzadeh et al. 2011; Sule et al. 2011). The inconsistence of these ratios was not unexpected because of their possible instability, which has been reported previously (Sany et al. 2014; Saha et al. 2009; Jiang et al. 2009; Adeniji et al. 2018a, b). Notwithstanding, petrogenic diagnosis in the estuary water may be attributed to possible leakage of fuel from two-stroke engines of the fishing boats and yacht in the area (Nukpezah 2010; Gorleku et al. 2014). BaA/BaA + Chry is more peculiar among the ratios used. Values $<0.2$ usually indicate petrogenic origin, between 0.2 and 0.35 points to combustion of petroleum products, whereas combustion of wood, grass, and/or coal will be suspected if higher than 0.35 . Table 3 shows values $>0.35$ for both water and sediment, implying contributions from the burning of nonpetroleum materials, such as refuse or biomass as another major pyrolytic input. This assertion was confirmed in the sediment samples with the use of $\mathrm{BaA} / 228$ (Jiao et al. 2012; Zhao et al. 2017).

The overall assessment of the result points to a predominant pyrogenic contamination of the two matrices in the aquatic environment (Menzie et al. 2002; Okoro 2008), largely due to influx of runoff from the highways, discharge of treated or untreated effluents, air deposition or incomplete combustion of biomass (wood, plants, domestic wastes) deposited on a dumpsite in the surroundings, and/or stormwater from the nearby port activities (Doan 2005; Kafilzadeh et al. 2011; Sule et al. 2011; Nekhavhambe et al. 2014; Błaszczyk et al. 2017).

\section{Probable Carcinogenic and Mutagenic Toxicities of PAHs in the Estuary Sediment}

Concentrations of the 7 PAHs (BaA, Chry, BbF, BkF, BaP, DiahA, and InPy) with probable carcinogenic potentials 
(Lerda 2011) ranged from 674 to $15,326 \mu \mathrm{g} / \mathrm{kg} \mathrm{dw}$ in sediment samples (mean concentration of $2875 \pm 872 \mu \mathrm{g} / \mathrm{kg}$ $\mathrm{dw}$ ). The carcinogenic PAHs (cPAHs) accounted for $56.82 \%$ of the total concentrations of the 16 priority PAHs in the sediment samples (Table 2). The highest concentration of cPAHs in the sediment was recorded from second creek, E3 $(4073 \mu \mathrm{g} / \mathrm{kg})$, suggesting that industrial effluent discharges and leachate from landfill site contribute hugely to the pollution of the estuary. Moreover, indeno(1,2,3-c,d)pyrene, a reliable indicator of incomplete combustion of PAHs was the highest cPAH detected in the sediment samples, indicating that emission from vehicle exhausts is another major pollution source in the study area (Stogiannidis and Laane 2015).

The evaluated potential carcinogenic (TEQ) and mutagenic (MEQ) toxicities of PAHs in the estuary sediment are shown in Fig. 5. The total TEQ obtained was $1213 \mu \mathrm{g} / \mathrm{kg}$, of which BaP $(191 \mu \mathrm{g} / \mathrm{kg})$ and DiahA $(854 \mu \mathrm{g} / \mathrm{kg})$ made significant contributions of $11 \%$ and $70 \%$, respectively. This was very consistent with the account of Kumar et al. (2014b). Likewise, the overall MEQ recorded in this study was $932 \mu \mathrm{g} / \mathrm{kg}$, predominated with BaP $(191 \mu \mathrm{g} / \mathrm{kg})$, DiahA $(248 \mu \mathrm{g} / \mathrm{kg})$, and InPy $(278 \mu \mathrm{g} / \mathrm{kg})$, in a similar manner as reported by Benson et al. (2017). The large influence of $\mathrm{BaP}$ and DiahA in both TEQ and MEQ revealed that exposure to the estuary sediment can possibly generate cancer risk and some other noncancer-based health issues that can negatively impact upon the DNA (deoxyribonucleic acid) in humans (Salem et al. 2014; Hussein et al. 2016; Benson et al. 2017; Błaszczyk et al. 2017).

\section{Assessment of Health Risk to Humans in the Estuary Water}

PAHs bioconcentrate and bio-accumulate in organisms through inhalation, ingestion, and/or dermal contact route(s) (Kumar et al. 2014b; Adeniji et al. 2018a, b). The health

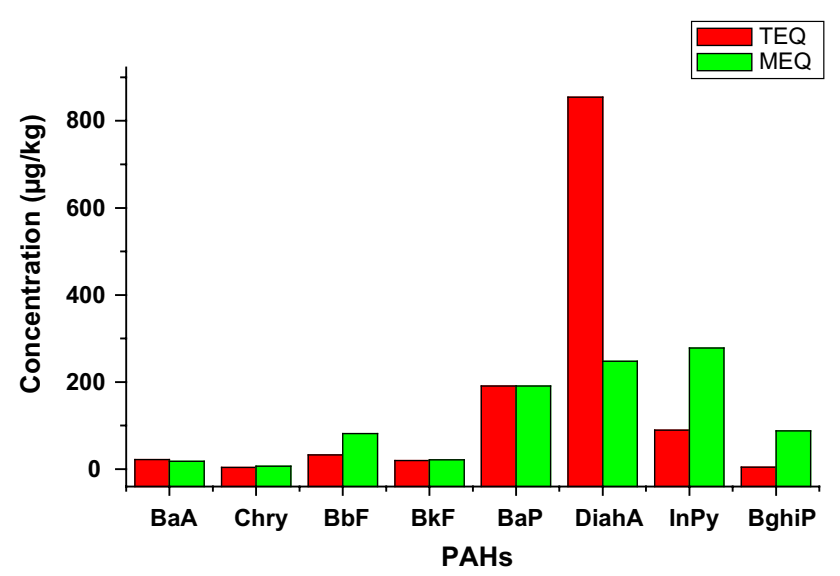

Fig. 5 Ecological risk assessment of PAHs in Buffalo River Estuary
Table 4 HQs of PAHs in the surface water samples from Buffalo River Estuary by dermal contact

\begin{tabular}{lllll}
\hline PAHs & $\mathrm{Kp}(\mathrm{cm} / \mathrm{h})$ & RfD & Children & Adults \\
\hline Naphthalene & $6.90 \times 10^{-2}$ & 0.02 & $1.01 \times 10^{-2}$ & $3.43 \times 10^{-3}$ \\
Fluorene & - & 0.04 & - & - \\
Anthracene & - & 0.04 & - & - \\
Phenanthrene & $2.70 \times 10^{-1}$ & 0.04 & $1.02 \times 10^{-2}$ & $3.47 \times 10^{-3}$ \\
Fluoranthene & $3.60 \times 10^{-1}$ & 0.04 & $9.11 \times 10^{-4}$ & $3.09 \times 10^{-4}$ \\
Benzo(g,h,i)perylene & - & 0.04 & - & - \\
HI & & & $2.13 \times 10^{-2}$ & $7.2 \times 10^{-3}$ \\
\hline
\end{tabular}

$P A H s$ polycyclic aromatic hydrocarbons, $R f D$ reference dose, $H I$ hazard index, $K p$ dermal permeability coefficient (Wei et al. 2015)

Table 5 ILCR of cPAHs in the surface water samples from Buffalo River Estuary by dermal contact

\begin{tabular}{lllll}
\hline PAHs & $\mathrm{Kp}(\mathrm{cm} / \mathrm{h})$ & $\mathrm{CSF}$ & Children & Adults \\
\hline Benzo(a)anthracene & $8.10 \times 10^{-1}$ & 0.73 & $2.83 \times 10^{-5}$ & $4.79 \times 10^{-5}$ \\
Chrysene & $8.10 \times 10^{-1}$ & 0.073 & $6.94 \times 10^{-6}$ & $1.18 \times 10^{-5}$ \\
Benzo(b)fluoranthene & 1.20 & 0.73 & $1.39 \times 10^{-4}$ & $2.36 \times 10^{-4}$ \\
$\begin{array}{l}\text { Benzo(k)fluoranthene } \\
\text { Benzo(a)pyrene }\end{array}$ & - & 0.73 & - & - \\
$\begin{array}{l}\text { Dibenzo(a,h)anthra- } \\
\quad \text { cene }\end{array}$ & 2.70 & 7.3 & $2.35 \times 10^{-4}$ & $3.98 \times 10^{-4}$ \\
$\begin{array}{l}\text { Indeno(1,2,3-cd) } \\
\text { pyrene }\end{array}$ & 1.90 & 0.73 & $5.72 \times 10^{-4}$ & $9.7 \times 10^{-4}$ \\
& & & & \\
\end{tabular}

$P A H s$ polycyclic aromatic hydrocarbons, CSF cancer slope factor, $c P A H s$ carcinogenic PAHs, $K p$ dermal permeability coefficient (Wang et al. 2009; CCME 2010; IARC 2010; Kumar et al. 2015; Wei et al. 2015; Benson et al. 2017; Błaszczyk et al. 2017)

risk in the Buffalo estuary water was assessed using dermal absorption pathway, being a recreational environment used for several activities, including yacht and rowing clubs. It also is believed to serve as nursery ground for marine invertebrates and fish, although yet to be proven (EOHCES 2016).

The estimated hazard quotients of PAHs in the estuary water by dermal absorption ranged from $9.11 \times 10^{-4}$ to $1.02 \times 10^{-2}$ and from $3.09 \times 10^{-4}$ to $3.47 \times 10^{-3}$ in children and adults, respectively (Table 4 ). The results indicate that HQs for both age categories in the water column were below the US EPA maximum limit of 1 . Hence, the chance of humans contracting any noncarcinogenic disease or other health-related issues by using the water for recreational purposes is very unlikely (ATSDR 2013; Wei et al. 2015; Benson et al. 2017). However, the dermal incremental lifetime cancer risk values calculated were higher. ILCRs varied between $6.94 \times 10^{-6}$ and $9.87 \times 10^{-4}$ for children and from $1.18 \times 10^{-5}$ to $1.67 \times 10^{-3}$ for adults, respectively, with chrysene and benzo(a)pyrene recording the lowest 
and highest values in that order (Table 5). The risk indices for the two groups were $1.97 \times 10^{-3}$ and $3.34 \times 10^{-3}$, correspondingly. In particular, 5 of the 7 cPAHs, which are benzo(b)fluoranthene, benzo(k)fluoranthene, benzo(a)pyrene, dibenzo(a,h)anthracene, and indeno(1,2,3-cd)pyrene exceeded the threshold value of $1 \times 10^{-4}$ (Wei et al. 2015; Wang et al. 2018).

It therefore could be inferred that Buffalo River Estuary water is unfit for swimming, because there is a chance that 1 in every 508 adults and 299 children who swim in the water are exposed to the risk of having cancer, respectively. This was in agreement with the Situation Assessment Report of the estuary earlier released (EOHCES 2016). It is worth mentioning that chances of adults' exposure to the carcinogenic risk is higher than for children (Karyab et al. 2016). Hence, necessary caution should be taken by everyone using the water and regulatory bodies should as well ensure that the pollution of the aquatic environment is controlled to ensure the safety of human and aquatic lives.

\section{Conclusions}

Although the total concentrations of PAHs found in the water and sediment of Buffalo River Estuary were above the regulatory limits, they were within the range of values reported from many other regions of the world. The two most polluted locations in the aquatic environment were E1 and E3. The levels of the pollutants were higher in summer than autumn and were predominantly from pyrolytic sources, especially from discharge of effluent from automobile and petrochemical industries, leachate from nearby landfill site, West Bank Hood Point domestic and industrial wastewater channels, vehicle emissions on the highways, harbour activities, as well as drains from urbanized subcatchments in the East London City Centre. Noncarcinogenic risk seems to be very unlikely in the water column, but the estimated carcinogenic risk by skin absorption was high. Similarly, TEQ and MEQ for benzo(a)pyrene and dibenzo(a,h)anthracene in the sediment were high, suggesting a possibility of carcinogenic and mutagenic hazards after frequent exposure. Adults seems to be more prone to higher level of risk than children. Therefore, necessary measures should be taken to address the level of contamination by the immediate users of the aquatic resources. Moreover, proper monitoring is needed in the area to safeguard human and aquatic lives in the area.

Acknowledgements The authors thank South African Medical Research Council (SAMRC) that provided funds for this research (UFH/SAMRC/P790), Sasol Inzalo and National Research Foundations (NRF) of South Africa for student's doctoral bursary, and University of Fort Hare for the enabling environment for the study.

\section{Compliance with Ethical Standards}

Conflict of interest There is no potential conflict of interest.

Open Access This article is distributed under the terms of the Creative Commons Attribution 4.0 International License (http://creativeco mmons.org/licenses/by/4.0/), which permits unrestricted use, distribution, and reproduction in any medium, provided you give appropriate credit to the original author(s) and the source, provide a link to the Creative Commons license, and indicate if changes were made.

\section{References}

Adekunle AS, Oyekunle JAO, Ojo OS, Maxakato NW, Olutona GO, Obisesan OR (2017) Determination of polycyclic aromatic hydrocarbon levels of groundwater in Ife north local government area of Osun state, Nigeria. Toxicol Rep 4:39-48

Adeniji AO, Okoh OO, Okoh AI (2017) Petroleum hydrocarbon fingerprints of water and sediment samples of Buffalo River Estuary in the Eastern Cape Province, South Africa. J Anal Methods Chem. https://doi.org/10.1155/2017/2629365

Adeniji AO, Okoh OO, Okoh AI (2018a) Analytical methods for polycyclic aromatic hydrocarbons and their global trend of distribution in water and sediment: a review. In: Manar El-Sayed AbdulRaouf (ed) Recent insights in petroleum science and engineering. ISBN: 978-953-51-5321-4. https://doi.org/10.5772/intechopen .71163

Adeniji AO, Okoh OO, Okoh AI (2018b) Distribution pattern and health risk assessment of polycyclic aromatic hydrocarbons in the water and sediment of Algoa Bay, South Africa. Environ Geochem Health. https://doi.org/10.1007/s10653-018-0213-x

Akkanen J, Tuikka A, Kukkonen JVK (2005) Comparative sorption and desorption of benzo[a]pyrene and 3,4,3', $4^{\prime}$-tetrachlorobiphenyl in natural lake water containing dissolved organic matter. Environ Sci Technol 39(19):7529-7534

ATSDR (Agency for Toxic Substances and Disease Registry) (1995) Toxicological profile for polycyclic aromatic hydrocarbons. Atlanta, GA: U.S. Department of Health and Human Services, Public Health Service, pp 11-173

ATSDR (Agency for Toxic Substances and Disease Registry) (2009) Case studies in environmental medicine: toxicity of polycyclic aromatic hydrocarbons (PAHs), pp 23-26

ATSDR (Agency for Toxic Substances and Disease Registry) (2013). Polycyclic aromatic hydrocarbons (PAHs): what health effects are associated with PAH Exposure? https://www.atsdr.cdc.gov/ csem/csem.asp?csem $=13 \& p o=11$. Accessed 29 Nov 2016

Balbo S, Turesky RJ, Villalta PW (2014) DNA adductomics. Chem Res Toxicol 27:356-366

Benson NU, Anake AE, Adedapo WU, Fred-Ahmadu OH, Eke KP (2017) Polycyclic aromatic hydrocarbons in imported Sardinops sagax: levels and health risk assessments through dietary exposure in Nigeria. J Food Comp Anal 57:109-116

Błaszczyk E, Rogula-Kozłowska W, Klejnowski K, Fulara I, Mielżyńska-Svach D (2017) Polycyclic aromatic hydrocarbons bound to outdoor and indoor airborne particles (PM2.5) and their mutagenicity and carcinogenicity in Silesian kindergartens, Poland. Air Qual Atmos Health 10:389-400. https://doi. org/10.1007/s11869-016-0457-5

Brazkova M, Krastanov A (2013) Polycyclic aromatic hydrocarbons: sources, effects and biodegradation. Научни Трудове На Русенския Университет, Том 10(2):1-5 
British Columbia (1993) Water quality. Ambient water quality criteria for polycyclic aromatic hydrocarbons (PAHs): Overview Report. Ministry of Environment, Lands and Parks, p 9

Cai S, Syage JA, Hanold KA, Balogh MP (2009) Ultra-performance liquid chromatography atmospheric pressure photo ionizationtandem mass spectrometry for high-sensitivity and high-throughput analysis of U.S. Environmental Protection Agency 16 priority pollutants polynuclear aromatic hydrocarbons. Anal Chem 81:2123-2128

CCME (Canadian Council of Ministers of the Environment) (2010). Canadian soil quality guidelines for carcinogenic and other polycyclic aromatic hydrocarbons (PAHs) (environmental and human health effects). Scientific Criteria Document (Revised), Publication No. 1445 [Internet]. http://www.ccme.ca/files/Resou rces/supporting_scientific_documents/pah_soqg_scd_1445.pdf Accessed 13 June 2016

Chigor VN, Sibanda T, Okoh AI (2012) Studies on the bacteriological qualities of the Buffalo River and three source water dams along its course in the Eastern Cape Province of South Africa. Environ Sci Pollut Res. https://doi.org/10.1007/s11356-012-1348-4

Chigor VN, Sibanda T, Okoh AI (2013) Variations in the physicochemical characteristics of the Buffalo River in the Eastern Cape Province of South Africa. Environ Monitor Assess 185:8733-8747

Chimuka L, Sibiya P, Amdany R, Cukrowska E, Forbes PBC (2015) Status of PAHs in environmental compartments of South Africa: a country report. Polycycl Aromat Compd 00:1-19

DEA (Department of Environmental Affairs, South Africa) (2010). Framework for the management of contaminated land, p 326

DEAT (Department of Environmental Affairs and Tourism) (2010). Theme: coast and estuaries, pp 1-19. http://soer.deat.gov.za/dm_ documents/Theme_Coast_cUAvQ.pdf. Accessed 15 Oct 2016

Doan M (2005) Concentrations of polycyclic aromatic hydrocarbons in surficial sediments of the Fore River and Portland Harbor, Maine. A Report to the Natural Resource Damage Trustees Agreement Number; 604195, pp 3-7

DoE (Department of Environment) (2003) Assessment levels for soil, sediment and water. Contaminated sites management series, Western Australia. Version 3, p 21

Dong C, Chen C, Chen C (2012) Determination of polycyclic aromatic hydrocarbons in industrial harbor sediments by GC-MS. Int J Environ Res Public Health 9:2175-2188

Douglas GS, Emsbo-Mattingly SD, Stout SA, Uhler AD, McCarthy KJ (2007) Chemical fingerprinting methods. In: Murphy BL, Morisson RD (eds) Introduction to environmental forensics, 2nd edn. Academic, New York, pp 311-454

DTSC (California Department of Toxic Substances Control) (2014) Human health risk assessment (HHRA) Note. Hero HHRA Note Number $1, \mathrm{p} 4$

Edokpayi JN, Odiyo JO, Popoola OE, Msagati TAM (2016) Determination and distribution of polycyclic aromatic hydrocarbons in rivers, sediments and wastewater effluents in Vhembe District, South Africa. Int J Environ Res Public Health 13:387. https://doi. org/10.3390/ijerph13040387

EOH Coastal and Environmental Services (EOHCES) (2016) Buffalo River Estuary, East London. Draft Situation Assessment Report, pp 31-49

Feng J, Hu P, Li X, Liu S, Sun J (2016a) Ecological and health risk assessment of polycyclic aromatic hydrocarbons (PAHs) in surface water from middle and lower reaches of the Yellow River. Polycycl Aromat Compd 36(5):656-670. https://doi. org/10.1080/10406638.2015.1042552

Feng J, Xi N, Zhang F, Zhao J, Hu P, Sun J (2016b) Distributions and potential sources of polycyclic aromatic hydrocarbons in surface sediments from an emerging industrial city (Xinxiang). Environ Monit Assess 188(1):61. https://doi.org/10.1007/s1066 1-015-5060-y
Gerba CP (2006) Chapter 14: Risk Assessment. In: Pepper IL, Gerba CP, Brusseau ML (eds) Environmental and pollution science, 2nd edn. Elsevier/Academic Press, Amsterdam, p 553

Gorleku MA, Carboo D, Palm LMN, Quasie WJ, Armah AK (2014) Polycyclic aromatic hydrocarbons (PAHs) pollution in marine waters and sediments at the Tema Harbour, Ghana. Acad J Environ Sci 2(7):108-115

Hasanati M, Savari A, Nikpour Y, Ghanemi K (2011) Assessment of the sources of polycyclic aromatic hydrocarbons in Mousa Inlet by molecular ratios. J Environ Stud 37(59):1-3

Hussein RA, Al-Ghanim KA, Abd-El-Atty MM, Mohamed LA (2016) Contamination of Red Sea Shrimp (Palaemon serratus) with polycyclic aromatic hydrocarbons: a health risk assessment study. Polish J Environ Studies 25(2):615-620

IARC (International Agency for Research on Cancer) (2006). Polycyclic aromatic hydrocarbons. IARC Monogaraph 92. Lyone France. http://monographs.iarc.fr/ENG/Meetings/92-pahs.pdf. Accessed 2 Feb 2014

IARC (International Agency for Research on Cancer) (2010). Monographs on the evaluation of carcinogenic risks to humans, vol 92. IARC, Lyon. http://monographs.iarc.fr/ENG/Monographs/vol92 /index.php. Accessed 11 Dec 2018

Jamhari AA, Sahani M, Latif MT, Chan KM, Tan HS, Khan MF, Tahir NM (2014) Concentration and source identification of polycyclic aromatic hydrocarbons (PAHs) in PM10 of urban, industrial and semi-urban areas in Malaysia. Atmos Environ 86:16-27

Jiang J, Lee C, Fang M, Liu JT (2009) Polycyclic aromatic hydrocarbons in coastal sediments of southwest Taiwan: an appraisal of diagnostic ratios in source recognition. Mar Pollut Bull 58:752-760. https://doi.org/10.1016/j.marpolbul.2008.12.017

Jiao W, Wang T, Khim JS, Luo W, Hu W, Naile JE, Giesy JP, Lu Y (2012) PAHs in surface sediments from coastal and estuarine areas of the northern Bohai and Yellow Seas, China. Environ Geochem Health 34(4):445-456

Kafilzadeh F, Shiva AH, Malekpour R (2011) Determination of polycyclic aromatic hydrocarbons (PAHs) in water and sediments of the Kor River, Iran. Middle East J Sci Res 10(1):1-7

Kang Y, Wang X, Dai M, Feng H, Li A, Song Q (2009) Black carbon and polycyclic aromatic hydrocarbons (PAHs) in surface sediments of China's marginal seas. Chin J Oceanol Limnol 27(2):297-308. https://doi.org/10.1007/s00343-009-9151-x

Karyab H, Yunesian M, Nasseri S, Rastkari N, Mahvi A, Nabizadeh R (2016) Carcinogen risk assessment of polycyclic aromatic hydrocarbons in drinking water, using probabilistic approaches. Iran J Public Health 45(11):1455-1464

KDHE (Kansas Department of Health and Environment) (2015) Kansas method for the determination of mid-range hydrocarbons (MRH) and high-range hydrocarbons (HRH). Revision 1:18-20

Kelly CA, Law RJ, Emerson HS (2000) Methods for analysis for hydrocarbons and polycyclic aromatic hydrocarbons (PAH) in marine samples. In: Science series, aquatic environment protection: analytical methods, vol 12. CEFAS, Lowestoft, 18 pp. http://www.cefas.co.uk/publications/aquatic/aepam12.pdf. Accessed 14 Sep 2018

Kennicutt MC II, Wade TL, Presley BJ, Requejo AG, Brooks JM, Denoux GJ (1994) Sediment contaminants in Casco Bay, Maine: inventories, sources, and potential for biological impact. Environ Sci Technol 28(1):1-15

Kennish MJ (1994) Pollution in estuaries and coastal marine waters. J Coast Res Coast Hazards Special Issue 12:27-49

Kumar B, Tyagi J, Verma VK, Gaur R, Sharma CS (2014a) Concentrations, source identification and health risk of selected priority polycyclic aromatic hydrocarbons in residential street soils. Adv Appl Sci Res 5(3):130-139

Kumar B, Verma VK, Gaur R, Kumar S, Sharma CS, Akolkar AB (2014b) Validation of HPLC method for determination of 
priority polycyclic aromatic hydrocarbons (PAHs) in waste water and sediments. Adv Appl Sci Res 5(1):201-209

Kumar B, Verma VK, Sharma CS, Akolkar AB (2015) Estimation of toxicity equivalency and probabilistic health risk on lifetime daily intake of polycyclic aromatic hydrocarbons from urban residential soils. Hum Ecol Risk Assess 21(2):434-444

Laboratory ESS (2008) Total petroleum hydrocarbons (SW846 Method 8100 Modified/Conn ETPH) by GC/FID. SOP 60_8100-mod. Revision 4:1-23

Lerda D (2011) Polycyclic aromatic hydrocarbons (PAHs) factsheet, 4th edition. JRC technical notes, 66955-2011, pp 6-13

Li G, Xia X, Yang Z, Wang R, Voulvoulis N (2006) Distribution and sources of polycyclic aromatic hydrocarbons in the middle and lower reaches of the Yellow River, China. Environ Pollut 144:985-993. https://doi.org/10.1016/j.envpol.2006.01.047

Li Y, Song N, Yu Y, Yang Z, Shen Z (2017) Characteristics of PAHs in street dust of Beijing and the annual wash-off load using an improved load calculation method. Sci Total Environ 581-582:328-336

Lin H, Xia X, Bi S, Jiang X, Wang H, Zhai Y, Wen W (2018) Quantifying bioavailability of pyrene associated with dissolved organic matter of various molecular weights to Daphnia magna. Environ Sci Technol 52:644-653

Ma J, Xiao R, Li J, Yu J, Zhang Y, Chen L (2010) Determination of 16 polycyclic aromatic hydrocarbons in environmental water samples by solid-phase extraction using multi walled carbon nanotubes as adsorbent coupled with gas chromatography-mass spectrometry. J Chromatogr A 1217:5462-5469

MacDonald DD, Ingersoll CG, Berger TA (2000) Development and evaluation of consensus-based sediment quality guidelines for freshwater ecosystems. Arch Environ Contam Toxicol 39:20-31

Menzie CA, Hoeppner SS, Cura JJ, Freshman JS, LaFrey EN (2002) Urban and suburban storm water runoff as a source of polycyclic aromatic hydrocarbons (PAHs) to Massachusetts estuarine and coastal environments. Estuaries 25:165-176

Mirza R, Faghiri I, Abedi E (2012) Contamination of polycyclic aromatic hydrocarbons in surface sediments of Khure-Musa Estuarine, Persian Gulf. World J Fish Mar Sci 4(2):136-141

Montoya D (2015) Pollution in Sydney Harbour: sewage, toxic chemicals and microplastics. NSW Parliamentary Research Service: Briefing Paper No 03/2015, pp 73-75

Motsara MR, Roy RN (2008) Guide to laboratory establishment for plant nutrient analysis. FAO Fertil Plant Nutr Bull 19:38-42

Moyo S, McCrindle R, Mokgalaka N, Myburgh J, Mujuru M (2013) Source apportionment of polycyclic aromatic hydrocarbons in sediments from polluted rivers. Pure Appl Chem 85(12):21752196. https://doi.org/10.1351/PAC-CON-12-10-08

Nekhavhambe TJ, van Ree T, Fatoki OS (2014) Determination and distribution of polycyclic aromatic hydrocarbons in rivers, surface runoff, and sediments in and around Thohoyandou, Limpopo Province, South Africa. Water SA 40(3):415-425

Nemcik M (2004) Low-level PAH analysis using the Finnigan Surveyor HPLC system with PDA Detection. Thermo Electron Corp Appl Note 341:1-2

Nukpezah D (2010) Corporate environmental governance in Ghana: studies on industrial level environmental performance in manufacturing and mining [thesis]. Germany: Brandenburg University of Technology, Cottbus

Okoro D (2008) Source determination of polynuclear aromatic hydrocarbons in water and sediment of a creek in the Niger Delta region. Afr J Biotechnol 7(3):282-285

Olatunji OS, Fatoki OS, Opeolu BO, Ximba BJ (2014) Determination of polycyclic aromatic hydrocarbons [PAHs] in processed meat products using gas chromatography: flame ionization detector.
Food Chem 156:296-300. https://doi.org/10.1016/j.foodc hem.2014.01.120

Olutona GO, Oyekunle JAO, Ogunfowokan AO, Fatoki OS (2016) Assessment of polybrominated diphenyl ethers in sediment of Asunle stream of the Obafemi Awolowo University, Ile-Ife, Nigeria. Environ Sci Pollut Res 23(21):21195-21205. https:// doi.org/10.1007/s11356-016-7270-4

Onojake MC, Osakwe JO, Omokheyeke O (2014) Source distribution of polycyclic aromatic hydrocarbons of an oil spill impacted site in Niger Delta, Nigeria. Eur Chem Bull 3(2):179-182

Perez-Padilla R, Schilmann A, Riojas-Rodriguez H (2010) Respiratory health effects of indoor air pollution. Int J Tuberc Lung Dis 14(9):1079-1086

Prabhukumar G, Pagilla K (2010) Polycyclic aromatic hydrocarbons in urban runoff. Sources, sinks and treatment: a review. In: DuPage River Salt Creek Workgroup [Internet]. Available from: http:// drscw.org/dissolvedoxygen/DPAH1.pdf. Accessed 03 May 2015

RHP (River Health Programme) (2004) State-of-rivers report: Buffalo River system. Department of Water Affairs and Forestry, pp 17-33

Saha M, Togo A, Mizukawa K, Murakami M, Takada H, Zakaria MP, Chiem NH, Tuyen BC, Prudente M, Boonyatumanond R, Sarkar SK, Bhattacharya B, Mishra P, Tana TS (2009) Sources of sedimentary PAHs in tropical Asian waters: differentiation between pyrogenic and petrogenic sources by alkyl homolog abundance. Mar Pollut Bull 58:189-200. https://doi.org/10.1016/j.marpo lbul.2008.04.049

Sakuma T, Leigh D, Seto C, Schreiber A, Wittrig R (2011) Analysis of polycyclic aromatic hydrocarbons ( $\mathrm{PAH})$, alkylated derivatives, and photo-degradation products in environmental and food samples using LC-FLD-MS/MS with Q TRAP ${ }^{\circledR}$ Technology. Food Environ AB SCIEX, pp 1-3

Salem D, Morsy F, El-Nemr A, El-Sikaily A, Khaled A (2014) The monitoring and risk assessment of aliphatic and aromatic hydrocarbons in sediments of the Red Sea, Egypt. Egypt J Aquat Res 40:333-348. https://doi.org/10.1016/j.ejar.2014.11.003

Sany SBT, Rezayi M, Hashim R, Salleh A, Mehdinia A, Safari O (2014) Polycyclic aromatic hydrocarbons in coastal sediment of Klang Strait, Malaysia: distribution pattern, risk assessment and sources. PLoS ONE 9(4):1-14

Smith KEC, Thullner M, Wick LY, Harms H (2011) Dissolved organic carbon enhances the mass transfer of hydrophobic organic compounds from non-aqueous phase liquids (NAPLs) into the aqueous phase. Environ Sci Technol 45(20):8741-8747

Stogiannidis E, Laane R (2015) Source characterization of polycyclic aromatic hydrocarbons by using their molecular indices: an overview of possibilities. Rev Environ Contam Toxicol 234:49-133. https://doi.org/10.1007/978-3-319-10638-0_2

Sule AM, Polkowska Ż, Namieśnik J (2011) Contamination of runoff water at Gdańsk airport (Poland) by polycyclic aromatic hydrocarbons (PAHs) and polychlorinated biphenyls (PCBs). Sensors 11:11901-11920

Titilawo Y, Adeniji A, Adeniyi M, Okoh A (2018) Determination of levels of some metal contaminants in the freshwater environments of Osun State, Southwest Nigeria: a risk assessment approach to predict health threat. Chemosphere 211:834-843. https://doi.org/10.1016/j.chemosphere.2018.07.203

Tornero V, d'Alcalà MR (2014) Contamination by hazardous substances in the gulf of Naples and nearby coastal areas: a review of sources, environmental levels and potential impacts in the MSFD perspective. Sci Total Environ 466-467:820-840

US EPA (United State Environmental Protection Agency) (2003) Methods for organic chemical analysis of municipal and industrial wastewater. Method 610-Polynuclear aromatic hydrocarbons, pp 146-152 
US EPA (United States Environmental Protection Agency) (1989) Risk assessment guidance for superfund volume I, Human health evaluation manual (part a): interim final. EPA/540/1-89/002; PB90-155581, p 289

US EPA (United States Environmental Protection Agency) (1992) Dermal exposure assessment: principles and applications. EPA/600/8-91/011B; Interim Report, p 389

US EPA (United States Environmental Protection Agency) (2001). Integrated Risk Information System (IRIS): Benzo[a]pyrene (CAS No.50-32-8)

US EPA (United States Environmental Protection Agency) (2009) RAGS: part F, supplemental guidance for inhalation risk assessment. EPA/540/R/070/002

US EPA (United States Environmental Protection Agency) (2015) Regional Screening Table. Updated 2015, p. 176. https://semsp ub.epa.gov/work/10/500011899.pdf. Accessed 8 Aug 2018

Van den Berg M, Birnbaum LS, Denison M, De Vito M, Farland W, Feeley M, Fiedler H, Hakansson H, Hanberg A, Haws L, Rose M, Safe S, Schrenk D, Tohyama C, Tritscher A, Tuomisto J, Tysklind M, Walker N, Peterson RE (2006) The 2005 World Health Organization reevaluation of human and Mammalian toxic equivalency factors for dioxins and dioxin-like compounds. Toxicol Sci 93(2):223-241

Wang B, Yu G, Yu YJ, Huang J, Hu HY, Wang LS (2009) Health risk assessment of organic pollutants in Jiangsu Reach of the Huaihe River, China. Water Sci Technol 59(5):907-916. https:// doi.org/10.2166/wst.2009.038

Wang L, Zhang S, Wang L, Zhang W, Shi X, Lu X, Li X (2018) Concentration and risk evaluation of polycyclic aromatic hydrocarbons in urban soil in the typical semi-arid city of Xi' an in Northwest China. Int J Environ Res Public Health 15:607. https://doi. org/10.3390/ijerph15040607

Wei H, Le Z, Shuxian L, Dan W, Xiaojun L, Lan J, Xiping M (2015) Health risk assessment of heavy metals and polycyclic aromatic hydrocarbons in soil at Coke Oven Gas Plants. Environ Eng Manag J 14(2):487-496

Whitfield AK, Baliwe NG (2013) A century of science in South African estuaries: bibliography and review of research trends. SANCOR Occas Rep 7:289

WHO (2014) Ambient (outdoor) air quality and health. Fact sheet N 313. Updated March 2014. http://www.who.int/mediacentre/facts heets/fs313/en/. Accessed 6 July 2018
Wild SR, Jones KC (1995) Polynuclear aromatic hydrocarbons in the United Kingdom environment: a preliminary source inventory and budget. Environ Pollut 88:91-108

Wilson NK, Chuang JC, Lyu C (2001) Levels of persistent organic pollutants in several child day care centers. J Exp Anal Environ Epidemiol 11:449-458

WSDE (Washington State Department of Ecology) (1997) Analytical methods for petroleum hydrocarbons. Department of Ecology Publications Distribution Center, Olympia, WA. Publication No. ECY 97-602, pp 65-100

Yahaya A, Okoh OO, Okoh AI, Adeniji AO (2017) Occurrences of organochlorine pesticides along the course of Buffalo River in the Eastern Cape of South Africa and its health implications. Int J Environ Res Public Health 14(11):1372. https://doi.org/10.3390/ ijerph14111372

Yahaya A, Adeniji AO, Okoh OO, Songca SP, Okoh AI (2018) Distribution of polychlorinated biphenyl and their possible health risks along the course of Buffalo River in the Eastern Cape Province of South Africa. Water SA 44(4):601-611. https://doi.org/10.4314/ wsa.v44i4.09

Yahaya A, Okoh OO, Agunbiade FO, Okoh AI (2019) Occurrences of phenolic derivatives in Buffalo River of Eastern Cape, South Africa: exposure risk evaluation. Ecotoxicol Environ Saf 171(4):887-893. https://doi.org/10.1016/j.ecoenv.2019.01.037

Yim UH, Hong SH, Shim WJ, Oh JR, Chang M (2005) Spatial-temporal distribution and characteristics of PAHs in sediments from Masan Bay, Korea. Mar Pollut Bull 50:319-326

Yu H, Huang GH, An CJ, Wei J (2011) Combined effects of DOM extracted from site soil/compost and biosurfactant on the sorption and desorption of PAHs in a soil-water system. J Hazard Mater 190(1-3):883-890

Zhao Z, Qin Z, Cao J, Xia L (2017) Source and ecological risk characteristics of PAHs in sediments from Qinhuai River and Xuanwu Lake, Nanjing, China. J Chem. https://doi. org/10.1155/2017/3510796

Zheng Z, He PJ, Shao LM, Lee DJ (2007) Phthalic acid esters in dissolved fractions of landfill leachates. Water Res 41(20):4696-4702 